\title{
The effect of activated silicon dioxide and betaine supplementation on quails' growth and productivity
}

\author{
Adi Ratriyanto (D), Sigit Prastowo (iD) and Nuzul Widyas (iD) \\ Department of Animal Science, Faculty of Agriculture, Universitas Sebelas Maret, Jl. Ir. Sutami 36A, Surakarta 57126, \\ Indonesia. \\ Corresponding author: Adi Ratriyanto, e-mail: ratriyanto@staff.uns.ac.id \\ Co-authors: SP: prastowo@staff.uns.ac.id, NW: nuzul.widyas@staff.uns.ac.id \\ Received: 16-03-2021, Accepted: 21-06-2021, Published online: 05-08-2021
}

doi: www.doi.org/10.14202/vetworld.2021.2009-2015 How to cite this article: Ratriyanto A, Prastowo S, Widyas N (2021) The effect of activated silicon dioxide and betaine supplementation on quails' growth and productivity, Veterinary World, 14(8): 2009-2015.

\begin{abstract}
Background and Aim: Silicon dioxide and betaine supplements are essential in the poultry diet to improve growth and laying performance. This study aimed to determine the effect of activated silicon dioxide (ASD) and betaine supplementation on quails' growth performance during the starter period and on follicular development and productive parameters at the onset of the laying period.
\end{abstract}

\begin{abstract}
Materials and Methods: The research used 1064 quails, aged 7 days. Four treatments were employed: A basal diet (control), a diet supplemented with 200 ppm ASD, a diet supplemented with $0.12 \%$ betaine, and a diet supplemented with a combination of $200 \mathrm{ppm}$ ASD and $0.12 \%$ betaine (ASD+Betaine). Each diet group included seven replicates of 38 quails. The observed parameters were the quails' growth performance during the starter period and follicular development and egg production during the onset of the laying period.
\end{abstract}

Results: The results showed that combined supplementation with ASD+Betaine improved the quails' growth performance during the starter period $(\mathrm{p}<0.05)$. However, these supplements, either as single feed additives or in combination, did not affect ovarian and follicular characteristics during the onset of the laying period. Still, ASD and betaine enhanced egg production and weight. The highest magnitude of change resulted from combined supplementation with ASD + Betaine $(\mathrm{p}<0.05)$.

Conclusion: The ASD+Betaine could be productively applied to quails' diets during the starter period and at the onset of the laying period.

Keywords: betaine, follicle, productive parameters, quail performance, silicon dioxide.

\section{Introduction}

Quails are potential egg producers and have been widely and intensively farmed [1]. Their small size and weight give them the potential to increase farmers' incomes because it costs less for farmers to maintain them [2]. Female quails (in this case, Coturnix coturnix japonica) reach sexual maturity at approximately 6-7 weeks of age, with a body weight of around 110$117 \mathrm{~g}[3,4]$, and they get to the peak of their egg production at the age of 15 weeks $[5,6]$. Egg production patterns are genetically programmed, but they may be modified by environmental factors, such as nutrition $[7,8]$. Kaye et al. [1] suggested that a high metabolic rate causes high egg production in quails, and nutritional modifications, such as adding supplements to feed, are commonly made to increase egg production $[9,10]$.

Activated silicon dioxide (ASD) is a natural mineral derived when pure silicon dioxide is activated by

Copyright: Ratriyanto, et al. Open Access. This article is distributed under the terms of the Creative Commons Attribution 4.0 International License (http://creativecommons.org/licenses/ by/4.0/), which permits unrestricted use, distribution, and reproduction in any medium, provided you give appropriate credit to the original author(s) and the source, provide a link to the Creative Commons license, and indicate if changes were made. The Creative Commons Public Domain Dedication waiver (http:// creativecommons.org/publicdomain/zero/1.0/) applies to the data made available in this article, unless otherwise stated. subjecting micronized silicon dioxide powder to an electromagnetic treatment [11]. Biologically, it applies a specific quantum of electromagnetic energy inside the gut, increasing the electronegativity of water and, thus, accelerating ion exchange $[11,12]$. In contrast to other silicon dioxide compounds, ASD has an organized structure, greater energy transfer potential, and greater surface contact with the environment $[13,14]$. ASD accelerates biochemical changes in the digestive tract, including enzymatic digestion, nutrient ionization, and nutrient transfer across cells. The cation exchange and absorption properties of silica, such as increasing feed retention time and decreasing intestinal emptying rates, improve nutrient absorption and feed efficiency in poultry [15-17]. ASD supplementation improves growth performance in broilers [18] and turkeys [13] and increases egg weight in quails [17]. Meanwhile, betaine is a naturally existing compound in plant and animal tissue [19]. Betaine is a methyl group donor and an organic osmolyte [20]. As a methyl group donor, betaine is necessary for the transmethylation reaction. The reaction forms biologically active substances, such as carnitine, creatine, phosphatidylcholine, and epinephrine $[8,20]$. Betaine is also a potential osmolyte since it exerts an osmoregulatory function over epithelial cells and digestive 
tract microflora. Thus, it can increase the digestibility of some nutrients $[8,21]$. Betaine supplementation positively affects growth in chickens [22-24] and egg production in chickens, ducks, and quails [25-27].

Previous studies have addressed the effects of silicon dioxide and betaine supplementation in poultry, although the results vary $[18,26]$. There is also a lack of information concerning ASD and betaine supplementation in quails on follicular development and productive parameters at the onset of the laying period. It is hypothesized that the ASD and betaine supplementation could improve the quails' growth performance and productive parameters.

This study aimed to determine the effect of ASD and betaine supplementation on quails' growth performance during the starter period and on follicular development and productive parameters at the onset of the laying period.

\section{Materials and Methods \\ Ethical approval}

The study was approved by the Animal Ethics Committee of Sebelas Maret University under registration No. AEC-062019-022/002/2019.

\section{Study period and location}

The study was conducted from May to July 2019 under natural tropical conditions on the experimental site belonging to Sebelas Maret University, Indonesia. During the experiment, the average ambient temperatures in the morning $(06.00 \mathrm{~h})$, midday $(12.00 \mathrm{~h})$, and evening $(18.00 \mathrm{~h})$ were $27.1^{\circ} \mathrm{C}, 33.6^{\circ} \mathrm{C}$, and $30.1^{\circ} \mathrm{C}$, respectively, and the average relative humidity levels at those times were $82.2 \%, 58.4 \%$, and $66.1 \%$, respectively.

\section{Quails, experimental design, and diets}

The study used 1064 female quails (C. coturnix japonica; 7 days of age), with an average initial body weight of $23.74 \pm 1.33 \mathrm{~g}$. The birds were distributed into groups receiving one of four dietary treatments in a completely randomized experimental design. Each treatment group consisted of seven replicates of 38 quails. The four treatments were as follows: A basal diet (control), a diet supplemented with 200 ppm ASD, a diet supplemented with $0.12 \%$ betaine, and a diet supplemented with a combination of $200 \mathrm{ppm}$ ASD and $0.12 \%$ betaine (ASD+Betaine). The level of supplementation was based on the manufacturers' recommendation. The dietary treatments were created by adding ASD (Silica $+98.3 \%$ purity; Ceresco Nutrition, Canada) or betaine ( ${ }^{\mathrm{TNI}}$ Betaine $96 \%$ purity; Nutreco, the Netherlands) or both. Table-1 shows the compositions of the starter basal diet and the supplemented diets.

The experiment followed standard management practice. The birds were raised in battery cages and had free access to both water and feed. The lighting schedule during the starting-growing period was $12 \mathrm{~h}$ light and $12 \mathrm{~h}$ dark, while during the laying period was $16 \mathrm{~h}$ light and $8 \mathrm{~h}$ dark [27].
Table-1: Composition and nutrient content of the basal diets.

\begin{tabular}{lcc}
\hline Ingredients & Starter & Layer \\
\hline Maize (\%) & 42.00 & 44.70 \\
Rice bran (\%) & 13.35 & 7.82 \\
Wheat bran (\%) & 7.25 & 5.00 \\
Soybean meal (\%) & 26.00 & 25.35 \\
Fish meal (\%) & 8.85 & 7.00 \\
Coconut oil (\%) & 0.85 & 2.60 \\
DL-methionine (\%) & 0.00 & 0.03 \\
Dicalcium phosphate & 0.00 & 0.60 \\
Limestone (\%) & 1.10 & 6.30 \\
Premix (\%) & 0.25 & 0.25 \\
NaCl (\%) & 0.35 & 0.35 \\
Nutrient content & & \\
Metabolizable energy (kcal/kg) & 2800 & 2800 \\
Crude protein (\%) & 22.01 & 20.00 \\
Crude fat (\%) & 3.96 & 4.55 \\
Crude fiber (\%) & 5.81 & 4.48 \\
Crude ash (\%) & 6.36 & 7.86 \\
Calcium (\%) & 1.04 & 3.35 \\
Available phosphorus (\%) & 0.41 & 0.46 \\
Lysine (\%) & 1.31 & 1.17 \\
Methionine (\%) & 0.42 & 0.41 \\
\hline
\end{tabular}

${ }^{1}$ The premix supplied the following per kilogram diets: 42,000 IU Vitamin A; 7000 IU Vitamin $D_{3} ; 28$ mg Vitamin $\mathrm{E} ; 7 \mathrm{mg}$ Vitamin $\mathrm{K}$; $7 \mathrm{mg}$ Vitamin B1; $18 \mathrm{mg}$ Vitamin B2; $2 \mathrm{mg}$ Vitamin B6; $42 \mathrm{mg}$ Vitamin B12; $88 \mathrm{mg}$ Vitamin C; $21 \mathrm{mg}$ calcium $D$-pantothenate; $140 \mathrm{mg}$ niacin; $35 \mathrm{mg}$ choline chloride; $420 \mathrm{mg}$ manganese; $70 \mathrm{mg}$ iron; $0.7 \mathrm{mg}$ iodine; $350 \mathrm{mg}$ zinc; $0.7 \mathrm{mg}$ cobalt; $14 \mathrm{mg}$ copper, $35 \mathrm{mg}$ sanoquin (antioxidant).

\section{Growth performance}

Between the ages of 7 and 42 days, the quails were given the starter diets, and, from the age of 43 days forward, they were given the layer diets. Feed consumption was measured daily, while body weights were measured weekly during the starter period until the birds were 42 days old to obtain growth performance data. The feed conversion ratio (FCR) was calculated by dividing the feed intake (FI) by weight gain [28]. The protein efficiency ratio (PER) was calculated as grams of weight gain per gram of protein intake. In contrast, the energy efficiency ratio (EER) was calculated as grams of weight gain per $100 \mathrm{kcal}$ of metabolizable energy (ME) intake [28].

\section{Follicular characteristics and the laying performance during the onset of the laying period}

Data on follicular characteristics were observed weekly from 35 to 70 days of age. Every week, two quails were chosen from each replicate and slaughtered. Their ovaries were removed immediately to measure the ovarian weights, numbers of yellow follicles, and largest follicle (F1 follicle) weights, according to Attia et al. [9]. During the laying period, feed consumption, egg production, and egg weight were recorded daily. Data were collected for egg production parameters from the day the quails laid their first eggs until they reached peak egg production between 13 and 15 weeks of age.

\section{Statistical analysis}

Data were analyzed through analysis of variance according to the following model: $\mathrm{y}_{\mathrm{ij}}=\mu+\alpha_{\mathrm{i}}+\varepsilon_{\mathrm{ij}}$, 
where, $\mu=$ the general mean; $\alpha_{i}=$ the effect of treatment; and $\varepsilon_{\mathrm{ij}}=$ experimental error. The mean difference $(p=0.05)$ was analyzed using Duncan's multiple range test, and the R Studio was applied for the statistical analyses [29].

\section{Results}

\section{Growth performance}

Combined supplementation with ASD+Betaine enhanced the quails' average daily gain (ADG; 3.08 g vs. $2.76 \mathrm{~g} ; \mathrm{p}=0.01$ ) and reduced the FCR ( 3.85 vs. $4.27 ; \mathrm{p}=0.03$ ) during the starting period compared with the non-supplemented diet, although the ASD and betaine single-supplement diets improved neither the ADG nor the FCR. Other growth performance parameters, including FI, PER, and EER, were not affected by these supplements at all (Table-2).

\section{Follicular characteristics}

The treatments did not affect quails' ovarian weights from 35 to 70 days of age, although a numerical increase from 56 to 70 days of age in the supplemented groups (Table-3). Furthermore, neither the follicle numbers nor the F1 follicle weights from 56 to 70 days of age were affected by the treatments (Table-4). In this study, yellow follicle numbers and F1 follicle weight was not measuredon 35,42 , and 49 days from the samples.

\section{Productive parameters}

In this study, supplementation with ASD or betaine as a single feed additive did not affect the age at which the quails laid their first eggs, although the birds that received ASD supplementation laid their first eggs later than the other quails ( $\mathrm{p}<0.04$; Table-5). Similarly, the age at which the quails reached $50 \%$ egg production (EP) was not influenced by these supplements alone or in combination. However, peak production was achieved at an earlier age following ASD+Betaine supplementation than with the non-supplemented diet (15.71 weeks vs. 14.00 weeks; $\mathrm{p}=0.02$ ).

The ASD, betaine, and ASD+Betaine diets did not affect EP on 49 and 56 days of age (Table-6). However, according to data collected on 63 and 70 days of age and during peak production, these supplements enhanced egg production - particularly the betaine and ASD+Betaine diets $(\mathrm{p}<0.05)$. The effects of ASD supplementation were observed on 63 days of age. The greatest improvements in EP were observed with the ASD+Betaine diet, as opposed to the non-supplemented diet, on 63 (54.49\% vs. $39.87 \%$; $<<0.01)$ and 70 days of age $(69.36 \%$ vs. $53.25 \%$; $<<0.01)$ and during peak production $(81.61 \%$ vs. $75.98 \%$; $\mathrm{p}=0.03)$. The ASD, betaine, and ASD+Betaine diets did not affect egg weight on 49 days of age (Table-7).

Table-2: Growth performance of quails fed ASD and betaine during starter period.

\begin{tabular}{lccccc}
\hline Treatments & FI $(\mathbf{g} /$ day $)$ & ADG $(\mathbf{g})$ & FCR & PER & EER \\
\hline Control & $11.75 \pm 0.66$ & $2.76 \pm 0.20^{\mathrm{b}}$ & $4.27 \pm 0.28^{\mathrm{a}}$ & $1.07 \pm 0.07$ & $8.39 \pm 0.53$ \\
ASD & $11.63 \pm 0.65$ & $2.80 \pm 0.13^{\mathrm{b}}$ & $4.17 \pm 0.33^{\mathrm{a}}$ & $1.10 \pm 0.09$ & $8.62 \pm 0.71$ \\
Betaine & $11.82 \pm 0.39$ & $2.85 \pm 0.18^{\mathrm{b}}$ & $4.16 \pm 0.36^{\mathrm{a}}$ & $1.10 \pm 0.10$ & $8.63 \pm 0.77$ \\
ASD+Betaine & $11.84 \pm 0.37$ & $3.08 \pm 0.12^{\mathrm{a}}$ & $3.85 \pm 0.24^{\mathrm{b}}$ & $1.18 \pm 0.07$ & $9.30 \pm 0.59$ \\
p value & 0.91 & 0.01 & 0.03 & 0.13 & 0.12 \\
\hline
\end{tabular}

a,bDifferent superscripts in the same column indicated significant difference $(p<0.05)$. ASD=Activated silicon dioxide; $\mathrm{FI}=$ Feed intake; $\mathrm{ADG}=$ Average daily gain; $\mathrm{FCR}=$ Feed conversion ratio; $\mathrm{PER}=$ Protein efficiency ratio; $E \mathrm{ER}=\mathrm{Energy}$ efficiency ratio

Table-3: Ovarian weight of quails fed ASD and betaine from 35 to 70 days of age $(\mathrm{g})$.

\begin{tabular}{|c|c|c|c|c|c|c|}
\hline Treatments & 35 days & 42 days & 49 days & 56 days & 63 days & 70 days \\
\hline Control & $0.06 \pm 0.02$ & $0.10 \pm 0.03$ & $0.12 \pm 0.09$ & $1.67 \pm 0.79$ & $3.71 \pm 1.19$ & $4.03 \pm 1.07$ \\
\hline ASD & $0.05 \pm 0.03$ & $0.10 \pm 0.04$ & $0.10 \pm 0.01$ & $1.79 \pm 0.42$ & $4.02 \pm 1.01$ & $5.32 \pm 0.92$ \\
\hline Betaine & $0.07 \pm 0.03$ & $0.10 \pm 0.03$ & $0.11 \pm 0.04$ & $2.93 \pm 1.99$ & $4.57 \pm 1.05$ & $5.66 \pm 1.74$ \\
\hline ASD+Betaine & $0.07 \pm 0.02$ & $0.11 \pm 0.06$ & $0.10 \pm 0.05$ & $2.02 \pm 0.61$ & $4.59 \pm 1.17$ & $4.93 \pm 0.47$ \\
\hline p value & 0.80 & 0.83 & 0.65 & 0.24 & 0.38 & 0.80 \\
\hline
\end{tabular}

ASD $=$ Activated silicon dioxide

Table-4: Follicle numbers and F1 follicle weights of quails fed ASD and betaine.

\begin{tabular}{|c|c|c|c|c|c|c|}
\hline \multirow[t]{2}{*}{ Treatments } & \multicolumn{3}{|c|}{ Yellow follicle numbers* (days) } & \multicolumn{3}{|c|}{ F1 follicle weight $(g) *($ days) } \\
\hline & 56 & 63 & 70 & 56 & 63 & 70 \\
\hline Control & $2.00 \pm 1.83$ & $3.00 \pm 0.82$ & $3.43 \pm 0.53$ & $1.34 \pm 0.58$ & $1.85 \pm 0.34$ & $2.38 \pm 0.38$ \\
\hline ASD & $3.40 \pm 0.71$ & $3.43 \pm 0.89$ & $3.50 \pm 0.79$ & $1.39 \pm 1.34$ & $1.99 \pm 0.24$ & $2.41 \pm 0.18$ \\
\hline Betaine & $3.50 \pm 1.22$ & $3.71 \pm 0.45$ & $3.80 \pm 0.49$ & $1.71 \pm 0.86$ & $2.14 \pm 0.44$ & $2.53 \pm 0.55$ \\
\hline ASD+Betaine & $3.20 \pm 1.30$ & $3.71 \pm 0.89$ & $4.00 \pm 0.49$ & $1.18 \pm 0.52$ & $2.35 \pm 0.71$ & $2.40 \pm 0.09$ \\
\hline$p$ value & 0.80 & 0.47 & 0.55 & 0.43 & 0.61 & 0.39 \\
\hline
\end{tabular}

*Yellow follicle numbers and F1 follicle weight cannot be measured at 35, 42, and 49 days from the samples. $\mathrm{ASD}=$ Activated silicon dioxide 
However, on 56,63 , and 70 days of age and during peak production, these supplements increased egg weight $(\mathrm{p}<0.05)$.

\section{Discussion}

\section{Growth performance}

In this study, neither ASD nor betaine improved growth performance in quails when supplemented as single feed additives. However, a synergistic effect between the supplements was observed in the ASD+Betaine diet, as the quails' ADG and FCR improved. Previous observations have indicated that adding betaine to quails' diets containing $20 \%$ crude protein $(\mathrm{CP})$ increases weight gain [30], a finding that differs from the results of this study. However, the starter diet in this research contained $22 \% \mathrm{CP}$, which may have affected the betaine efficacy [31]. Betaine donates its methyl groups to form methylated compounds, including methionine, contributing to protein metabolism [20]. The efficacy of betaine as methyl group donor decreases with increasing protein content in the diet [32]. Other observations have indicated that betaine improves weight gain and feed conversion in broiler chickens [24,32] and meat-type ducks [33], though still, other studies have not found any effects of betaine on growth performance in broiler chickens [34]. Tran et al. [13] have observed that silicon dioxide supplementation improves weight gain and

Table-5: Age at some production criteria of quails fed ASD and betaine.

\begin{tabular}{lccc}
\hline Treatments & $\begin{array}{c}\text { First egg } \\
\text { (week) }\end{array}$ & $\begin{array}{c}\mathbf{5 0 \%} \text { EP } \\
\text { (week) }\end{array}$ & $\begin{array}{c}\text { Peak production } \\
\text { (week) }\end{array}$ \\
\hline Control & $6.76^{\mathrm{b}}$ & 9.00 & $15.71^{\mathrm{a}}$ \\
ASD & $7.06^{\mathrm{a}}$ & 9.29 & $14.43^{\mathrm{b}}$ \\
Betaine & $6.96^{\mathrm{b}}$ & 8.86 & $14.71^{\mathrm{b}}$ \\
ASD+Betaine & $6.61^{\mathrm{b}}$ & 8.71 & $14.00^{\mathrm{b}}$ \\
p value & 0.04 & 0.16 & 0.02 \\
\hline
\end{tabular}

$a, b$ Different superscripts in the same column indicated significant difference $(p<0.05$. ASD $=$ Activated silicon dioxide; $E P=E g g$ production feed conversion in turkey. Dietary silicate minerals have also enhanced the EER and PER in broilers [15]. However, studies using broilers [14] and turkey [35] have shown no growth performance improvement following ASD supplementation. Recent research indicates that silicon dioxide supplementation did not affect quails' growth until they reach the age of 7 weeks, but its effect increases at weeks 8 and 9 [36].

Both ASD and betaine can enhance nutrient absorption in the intestine [14,17,27], although numerical increases in ADG and FCR due to these supplements when included as single feed additives were not significant. When applied together, ASD and betaine facilitate higher nutrient availability and absorption, leading to improved ADG and FCR. Dietary silicate minerals reduce the gastrointestinal passage rate that nutrients are exposed to digestion longer [15], while betaine improves the morphology of intestinal cells, providing a more intact area surface for nutrient absorption [8]. Silicon dioxide and betaine help nutrient digestibility by improving the intestinal lumen's environment and decreasing osmolality $[8,15,17,37]$. In all cases, the efficacy of feed additive supplementation is affected by several factors, including the species and type of poultry, the environmental conditions, and the nutrient content of the diet [23].

\section{Follicular characteristics}

The ovarian weight gradually increased as the quails grew older. Ovarian size is influenced by the number and weight of those follicles. In this quail species, the ovaries are grape-shaped organs responsible for egg follicle growth and maturation [38]. In mature quails, the ovarian weight ranged between 3.5 and $6.5 \mathrm{~g}$ [39]. Follicles had not developed in the ovaries between 35 and 49 days of age but had begun developing by 56 days, as evidenced by the follicular weight measured on 56-70 days. Previous findings have shown that betaine stimulates the anterior pituitary gland to increase the secretion of follicle-stimulating and luteinizing hormones. These hormones

Table-6: Egg production at the onset of laying period of quails fed ASD and betaine (\%)

\begin{tabular}{lccccc}
\hline Treatments & 49 days & 56 days & 63 days & 70 days & Peak production \\
\hline Control & $2.14 \pm 1.93$ & $22.09 \pm 3.30$ & $39.87 \pm 2.45^{\mathrm{d}}$ & $53.25 \pm 4.62^{\mathrm{c}}$ & $75.98 \pm 5.53^{\mathrm{b}}$ \\
ASD & $2.54 \pm 1.40$ & $21.74 \pm 4.26$ & $45.67 \pm 2.47^{\mathrm{c}}$ & $56.12 \pm 1.75^{\mathrm{c}}$ & $75.26 \pm 4.99^{\mathrm{b}}$ \\
Betaine & $3.48 \pm 2.49$ & $24.74 \pm 3.08$ & $49.48 \pm 3.59^{\mathrm{b}}$ & $62.75 \pm 4.78^{\mathrm{b}}$ & $78.73 \pm 4.23^{\mathrm{a}}$ \\
ASD+Betaine & $3.14 \pm 2.23$ & $23.62 \pm 4.69$ & $54.49 \pm 2.90^{\mathrm{a}}$ & $69.36 \pm 4.26^{\mathrm{a}}$ & $81.61 \pm 2.59^{\mathrm{a}}$ \\
p value & 0.85 & 0.07 & $<0.01$ & $<0.01$ & 0.03 \\
\hline
\end{tabular}

$a, b, c, d$ Different superscripts in the same column indicated significant difference $(p<0.05)$. ASD=Activated silicon dioxide

Table-7: Egg weight at the onset of laying period of quails fed ASD and betaine $(\mathrm{g})$.

\begin{tabular}{lccccc}
\hline Treatments & 49 days & 56 days & 63 days & 70 days & Peak production \\
\hline Control & $8.75 \pm 0.88$ & $8.90 \pm 0.64^{\mathrm{b}}$ & $9.00 \pm 0.41^{\mathrm{b}}$ & $9.00 \pm 0.49^{\mathrm{b}}$ & $9.30 \pm 0.27^{\mathrm{b}}$ \\
ASD & $8.98 \pm 0.25$ & $9.40 \pm 0.48^{\mathrm{a}}$ & $9.50 \pm 0.30^{\mathrm{a}}$ & $9.85 \pm 0.67^{\mathrm{a}}$ & $9.92 \pm 0.19^{\mathrm{a}}$ \\
Betaine & $8.91 \pm 0.54$ & $9.54 \pm 0.35^{\mathrm{a}}$ & $9.65 \pm 0.27^{\mathrm{a}}$ & $9.82 \pm 0.64^{\mathrm{a}}$ & $9.97 \pm 0.36^{\mathrm{a}}$ \\
ASD+Betaine & $8.60 \pm 0.38$ & $9.50 \pm 0.34^{\mathrm{a}}$ & $9.73 \pm 0.80^{\mathrm{a}}$ & $9.91 \pm 0.37^{\mathrm{a}}$ & $9.92 \pm 0.29^{\mathrm{a}}$ \\
p value & 0.7 & 0.04 & $<0.01$ & $<0.01$ & $<0.01$ \\
\hline
\end{tabular}

a,bDifferent superscripts in the same column indicated significant difference $(p<0.05)$. ASD=Activated silicon dioxide 
stimulate follicular growth and increase EP [40]. However, the non-significant effect of ASD+Betaine supplementation on ovarian weight in this research could have been caused by these supplements having no effect on follicle development during the starting or growing periods and at the onset of the laying period. The synergistic effect of ASD and betaine in increasing the nutrient absorption during these periods was expressed in growth performance improvement rather than improvement in follicular growth and productive performance. This finding was per the improvement in ADG and FCR of the ASD+Betaine group. Previous research indicates that betaine supplementation did not affect EP in quails at the onset of the laying period, a result likely due to a high standard deviation [41]. Similarly, a study in quails indicated that betaine did not affect EP during 42-63 days, but the effect of betaine is more apparent after 70 days of age [42]. No study has been previously conducted concerning the effects of silicon dioxide supplementation on follicular characteristics. However, observations in laying hens showed that dietary inclusion of silicon [43] or nano-silicon dioxide [17] did not improve EP, indicating that silicon did not affect follicle development.

The single left ovary in $C$. coturnix japonica contains a hierarchy of growing follicles, gradually progressing toward maturity [44]. Large pre-ovulatory follicles are selected from the pool of small follicles and enter a rapid growth phase, while the vast majority become atretic $[38,40]$. These developing follicles are categorized by size and color: Large, white or small, and yellow follicles [40]. Follicle development to maturation in Coturnix quails is rapid, which occurs about 6 days [45]. This research observed the enhancement of F1 follicle numbers and weights when the quails were 56-70 days. Thus, the observed follicles were still immature, and EP was increasing toward peak production. Follicular maturation occurs when an ovum ceases to develop rapidly. Mature follicles can only be observed during a short time since the rest period between follicle maturation and oviposition is 0.1 days [40,45].

Follicle weight and numbers increase as body age increases [45]. In addition, at the onset of the laying period, the bodyweight of quails is still increasing, influencing ovary and follicle size. Quails with body weights of 120-130 g have an F1 follicle weight of $2.31 \mathrm{~g}$, while quails with body weights of $150-160 \mathrm{~g}$ have F1 follicle weights of $3.34 \mathrm{~g}$ [46]. In most birds, ovaries show five follicle sizes (largest to smallest: F1, F2, F3, F4, and F5); small, yellow follicles, and numerous white follicles [38,47]. Ovarian follicular activities and hierarchies may be attributed to genetics, as well as to nutritional and management conditions $[40,47]$.

\section{Productive parameters}

Supporting the finding in productive parameters, Ratriyanto [42] did not observe any influence on age at the start of the laying period or on $50 \% \mathrm{EP}$ when betaine was added to quails' diets containing $18.7 \%$ protein. In that study [42], the first egg was laid when the quails were 6 weeks of age, and 50\% EP was achieved after 8 weeks of age. These results were in the normal range for quails, which reach sexual maturity at about 6-7 weeks of age and reach a peak EP at approximately 15 weeks of age $[1,6]$. As with the follicular characteristics above, there was no literature examining silicon dioxide supplementation on age at various production parameters in quails.

The ASD, betaine, and ASD+Betaine diets did not affect EP on 49 and 56 days of age (Table-6). However, according to data collected on 63 and 70 days of age and during peak production, these supplements enhanced egg production - particularly the betaine and ASD+Betaine diets $(\mathrm{p}<0.05)$. The effects of ASD supplementation were observed only on 63 days of age. The highest improvements in EP were observed with the ASD+Betaine diet, as opposed to the non-supplemented diet, on $63(54.49 \%$ vs. $39.87 \%$; $<<0.01)$ and 70 days of age $(69.36 \%$ vs. $53.25 \% ; \mathrm{p}<0.01)$ and during peak production $(81.61 \%$ vs. $75.98 \% ; \mathrm{p}=0.03)$. The greatest improvement observed in ASD+Betaine group could be attributed to the synergistic effect of ASD and betaine in improving nutrient absorption leading to higher nutrient availability for EP. As explained previously, ASD and betaine can increase nutrient absorption in the intestine [14,17,27]. EP on 49 and 56 days of age was still relatively low since the quails were in the early stages of the production period, and production was not yet stable [7]. The low rate of follicle recruitment could cause low EP at the onset of the laying period into the yellow follicle hierarchy [39]. The previous studies indicate that the effects of betaine supplementation are observable at 10 weeks of age $[41,42]$.

The productive performance improvement following the ASD and betaine diets may be attributable to increased nutrient availability for EP. Betaine improves nutrient digestibility [9,31], which further enhances productive traits, such as EP, egg weight, and feed conversion, in laying poultry $[9,26]$, ducks [25], and quails [27,31]. Betaine supplementation, at $0.10 \%$, has increased the yolk weight of chicken eggs [9]. Another study shows that betaine supplementation in quails' diets, containing 2800 $\mathrm{kcal} / \mathrm{kg} \mathrm{ME}$ and $17 \%$ protein, enhanced egg weight by $3.82 \%$ [31]. Betaine also increases the levels of estrogen and progesterone in the blood. These hormones regulate ovulation and oviductal development [48]. ASD acts as a catalyst, accelerating biochemical changes in the digestive tract, which improves nutrient absorption [37]. Safaeikatouli et al. [15] illustrated that silicate minerals make temporary links with nutrients, decrease gastrointestinal transmission rates, and allow nutrients to digest further, thus increasing nutrient absorption. A previous study demonstrates that 
nano-silicon dioxide supplementation in quails' diets does not affect EP but increases egg weight during 16-20 weeks of age [17].

\section{Conclusion}

Only ASD+Betaine supplementation improved quails' growth performance during the starter period. However, ASD and betaine, either as single feed additives or combined, did not affect ovarian and follicular characteristics at the onset of the laying period. ASD and betaine also improved quails' productive parameters, as indicated by enhanced EP and weight; the highest magnitude was achieved through the ASD+Betaine diet. Thus, combined ASD and betaine could be beneficially applied to quails' diets during the starter period and at the onset of the laying period.

\section{Authors' Contributions}

AR: Conception and design, conducted the experiment, data acquisition, data analysis and interpretation, manuscript drafting, and revision. SP: Conception and design, manuscript drafting, and revision. NW: Data analysis and interpretation and manuscript drafting. All authors read and approved the final manuscript.

\section{Acknowledgments}

The authors wish to thank the Directorate General of Higher Education of the Republic of Indonesia for funding this research (Contract No. 719/UN27.21/ PN/2019). We are also grateful to A. P. Dewi, S. Rahayu, R. B. Aji, T. Esmak, and Z. E. Aryaza for their collaboration and assistance during the experimental work.

\section{Competing Interests} interests.

The authors declare that they have no competing

\section{Publisher's Note}

Veterinary World remains neutral with regard to jurisdictional claims in published institutional affiliation.

\section{References}

1. Kaye, J., Luka, S.J., Akpa, G.N. and Adeyinka, I.A. (2017) Egg production pattern of Japanese quail (Coturnix coturnix japonica) in Northern Guinea Savannah Zone of Nigeria. Int. J. Innov. Res. Adv. Stud., 4(1): 93-97.

2. Faitarone, A., Pavan, A., Mori, C., Batista, L., Oliveira, R., Garcia, E., Pizzolante, C., Mendes, A. and Sherer, M. (2007) Economic traits and performance of Italian quails reared at different cage stocking densities. Rev. Bras. Cienc. Avic., 7(1): 19-22.

3. Pu, S., Nagaoka, K. and Watanabe, G. (2019) Yolk immunoreactive corticosterone in hierarchical follicles of Japanese quail (Coturnix japonica) exposed to heat challenge. Gen. Comp. Endocrinol., 279: 148-153.

4. Piao, J., Okamoto, S., Kobayashi, S., Wada, Y. and Maeda, Y. (2004) Purebred and crossbred performances from a Japanese quail line with very small body size. Anim. Res. EDP Sci. Res., 53(2): 145-153.

5. Narinc, D., Aygun, A. and Sari, T. (2013) Effects of cage type and mating ratio on fertility in Japanese quails (Coturnix coturnix japonica) eggs. Agric. Sci. Dev., 2(1): 4-7.

6. Narinc, D., Uckardes, F. and Aslan, E. (2014) Egg production curve analyses in poultry science. Worlds. Poult. Sci. J., 70(4): 817-828.

7. Pavlidis, H.O., Price, S.E. and Siegel, P.B. (2002) Associations between egg production and clutch length in four selected lines of chickens. J. Appl. Poult. Res., 11(3): 304-07.

8. Ratriyanto, A. and Mosenthin, R. (2018) Osmoregulatory function of betaine in alleviating heat stress in poultry. J. Anim. Physiol. Anim. Nutr., 102(8): 1634-1650.

9. Attia, Y.A., Abd-El-Hamid, A.E.E., Abedalla, A.A., Berika, M.A., Al-Harthi, M.A., Kucuk, O., Sahin, K. and Abou-Shehema, B.M. (2016) Laying performance, digestibility and plasma hormones in laying hens exposed to chronic heat stress as affected by betaine, Vitamin C, and/or Vitamin E supplementation. Springerplus, 5(1): 1619.

10. Park, J.H. and Kim, I.H. (2019) The effects of betaine supplementation in diets containing different levels of crude protein and methionine on the growth performance, blood components, total tract nutrient digestibility, excreta noxious gas emission, and meat quality of the broiler chicks. Poult. Sci., 98(12): 6808-6815.

11. Decaux, C. (2017) Activated silicon dioxide to achieve a synergistic effect in pigs. Int. Pig Top., 32(1): 25.

12. Decaux, C. (2016) Electromagnetic technology: A new gut health approach. Gut Health, 10: 2-4.

13. Tran, S.T., Bowman, M.E. and Smith, T.K. (2015) Effects of a silica-based feed supplement on performance, health, and litter quality of growing turkeys. Poult. Sci., 94(8): 1902-1908.

14. Anshory, I., Sumiati, S. and Wijayanti, I. (2017) Evaluation of silica+ supplementation in different types of diet on performance, nutrient retention and the economic value of broilers diet Bull. Anim. Sci., 41(4): 461-471.

15. Safaeikatouli, M., Boldaji, F., Dastar, B. and Hassani, S. (2012) The effect of dietary silicate minerals supplementation on apparent ileal digestibility of energy and protein in broiler chickens. Int. J. Agric. Biol., 14(2): 299-302.

16. Sakai-Kato, K., Hidaka, M., Un, K., Kawanishi, T. and Okuda, H. (2014) Physicochemical properties and in vitro intestinal permeability properties and intestinal cell toxicity of silica particles, performed in simulated gastrointestinal fluids. Biochim. Biophys. Acta Gen. Subjects, 1840(3): 1171-1180.

17. Faryadi, S. and Sheikhahmadi, A. (2017) Effect of nanosilicon dioxide on growth performance, egg quality, liver histopathology and concentration of calcium, phosphorus and silicon in egg, liver and bone in laying quails. Appl. Nanosci., 7(8): 765-772.

18. Maradon, G.G., Sumiati, S., Mutia, R. and Winarsih, W. (2017) Evaluation of using Silica $+^{\circledR}$ as a feed additive on minerals metabolism, health status and excreta quality of broiler. Bull. Anim. Sci., 41(3): 285-297.

19. Lipiński, K., Szramko, E., Jeroch, H. and Matusevičius, P. (2012) Effects of betaine on energy utilization in growing pigs a review. Ann. Anim. Sci., 12(3): 291-300.

20. Metzler-Zebeli, B.U., Eklund, M. and Mosenthin, R. (2009) Impact of osmoregulatory and methyl donor functions of betaine on intestinal health and performance in poultry. Worlds. Poult. Sci. J., 65(3): 419-442.

21. Egbuniwe, I.C., Ayo, J.O. and Ocheja, O.B. (2018) Betaine and ascorbic acid modulate indoor behavior and some performance indicators of broiler chickens in response to hotdry season. J. Therm. Biol., 76(6): 38-44.

22. Akhavan-Salamat, H. and Ghasemi, H.A. (2016) Alleviation of chronic heat stress in broilers by dietary supplementation of betaine and turmeric rhizome powder: Dynamics of performance, leukocyte profile, humoral immunity, and antioxidant status. Trop. Anim. Health Prod., 48(1): 181-188. 
23. Alhassani, D.H. and Alsukhri, A.Y. (2016) Comparative efficacy of different supplements with drinking water used to alleviate body temperature of heat-stressed broiler chickens. Iraq. J. Agric. Sci., 47(Special Issue): 12-18.

24. Chand, N., Naz, S., Maris, H., Khan, R.U., Khan, S. and Qureshi, M.S. (2017) Effect of betaine supplementation on the performance and immune response of heat stressed broilers. Pak. J. Zool., 49(5): 1857-1862.

25. Awad, A.L., Ibrahim, A.F., Fahim, H.N. and Beshara, M.M. (2014) Effect of dietary betaine supplementation on growth performance and carcass traits of domati ducklings under summer conditions. Egypt. Poult. Sci. J., 34(2): 1019-1038.

26. Attia, Y.A., El-Hamid, A.E.A., Abdallah, A.A., Berikaa, M.A., El-Gandy, M.F., Sahin, K. and AbouShehema, B.M. (2018) Effect of betaine, Vitamin C and Vitamin $\mathrm{E}$ on egg quality, hatchability, and markers of liver and renal functions in dual-purpose breeding hens exposed to chronic heat stress. Eur. Poult. Sci., 82: 226.

27. Ratriyanto, A. and Prastowo, S. (2019) Floor space and betaine supplementation alter the nutrient digestibility and performance of Japanese quail in a tropical environment. J. Therm. Biol., 83(7): 80-86.

28. Kamran, Z., Sarwar, M., Nisa, M., Nadeem, M.A., Mahmood, S., Babar, M.E. and Ahmed, S. (2008) Effect of low-protein diets having constant energy-to-protein ratio on performance and carcass characteristics of broiler chickens from one to thirty-five days of age. Poult. Sci., 87(3): 468-474.

29. R Core Team. (2019) R: A Language and Environment for Statistical Computing. R Foundation for Statistical Computing, Vienna.

30. Rasul, M., Mehmood, S., Ahmad, S., Javid, A., Mahmud, A., Rehman, A., Usman, M., Hussain, J., Ahmad, M. and Azhar, M. (2019) Effects of different anti-stressors on growth, serum chemistry and meat quality attributes of Japanese quail. Rev. Bras. Cienc. Avic., 21(1): 1-10.

31. Ratriyanto, A., Indreswari, R. and Nuhriawangsa, A.M.P. (2017) Effects of dietary protein level and betaine supplementation on nutrient digestibility and performance of Japanese quails. Rev. Bras. Cienc. Avic., 19(3): 445-454.

32. Shakeri, M., Cottrell, J.J., Wilkinson, S., Ringuet, M., Furness, J.B. and Dunshea, F.R. (2018) Betaine and antioxidants improve growth performance, breast muscle development and ameliorate thermoregulatory responses to cyclic heat exposure in broiler chickens. Animals, 8(10): 1-16.

33. Park, S.O. and Kim, W.K. (2017) Effects of betaine on biological functions in meat-type ducks exposed to heat stress. Poult. Sci., 96(5): 1212-1218.

34. Pillai, P.B., Fanatico, A.C., Beers, K.W., Blair, M.E. and Emmert, J.L. (2006) Homocysteine remethylation in young broilers fed varying levels of methionine, choline, and betaine. Poult. Sci., 85(10): 90-95.

35. Majewska, T., Mikulski, D. and Siwik, T. (2009) Silica grit, charcoal and hardwood ash in Turkey nutrition. J. Elem., 14(3): 489-500.

36. Ratriyanto, A., Aryaza, Z.E., Prastowo, S. and Widyas, N. (2019) Digestibility enhancer affects quail growth trajectory at growing phase. AIP Conf. Proc., 2202: 020075.

37. Kasula, R. (2015) Silica+ a Natural and Unique Concept for Improving Animal Performance and Farm Environment. Ceresco Nutrition, Canada.

38. Etches, R.J. (1996) Reproduction in Poultry. CAB International, Wallingford, UK.

39. Saraswati, T.R., Manalu, W., Ekastuti, D.R. and Kusumorini, N. (2013) Increased egg production of Japanese quail (Cortunix japonica) by improving liver function through turmeric powder supplementation. Int. $J$. Poult. Sci., 12(10): 601-614.

40. Johnson, P.A. (2012) Follicle selection in the avian ovary. Reprod. Domest. Anim., 47(Suppl 4): 283-287.

41. Ratriyanto, A., Rosyidi, F., Prastowo, S. and Widyas, N. (2019) Egg production trajectories of quails fed moderate energy and protein levels supplemented with digestibility enhancer. IOP Conf. Ser. Earth Environ. Sci., 387: 012003.

42. Ratriyanto, A. (2018) Egg production pattern in quails fed diet supplemented with betaine and methionine. Caraka Tani J. Sustain. Agric., 33(1): 1-7.

43. Incharoen, T., Wonnakom, P. and Khaskheli, A.A. (2018) Performance and quality in old laying hens fed dietary silicon extracted from rice hull ash. Asian J. Anim. Vet. Adv., 13(2): 175-179.

44. Lovell, T.M., Gladwell, R.T., Groome, N.P. and Knight, P.G. (2003) Ovarian follicle development in the laying hen is accompanied by divergent changes in inhibin A, inhibin, B, activin $\mathrm{A}$ and follistatin production in granulosa and theca layers. J. Endocrinol. 177(1): 45-55.

45. Gupta, A. (2018) Gross morphological studies on ovaries of Punjab white quail. Int. J. Avian Wildl. Biol. 3(6): 423-425.

46. Arora, K.L. and Samples, O. (2011) Role of body weight on reproductive and physiological traits in Japanese quail layers (Coturnix japonica). Int. J. Poult. Sci. 10(8): 640-643.

47. Ratriyanto, A., Prastowo, S. and Widyas, N. (2018) Follicular characteristics of quails fed diets containing different nutrient contents. AIP Conf. Proc., 2014: 02006.

48. Kang, W.J., Yun, J.S., Seo, D.S., Hong, K.C. and Ko, Y. (2001) Relationship among egg productivity, steroid hormones (progesterone and estradiol) and ovary in Korean native chicken. Asian Australas. J. Anim. Sci., 14(7): 922-928. 